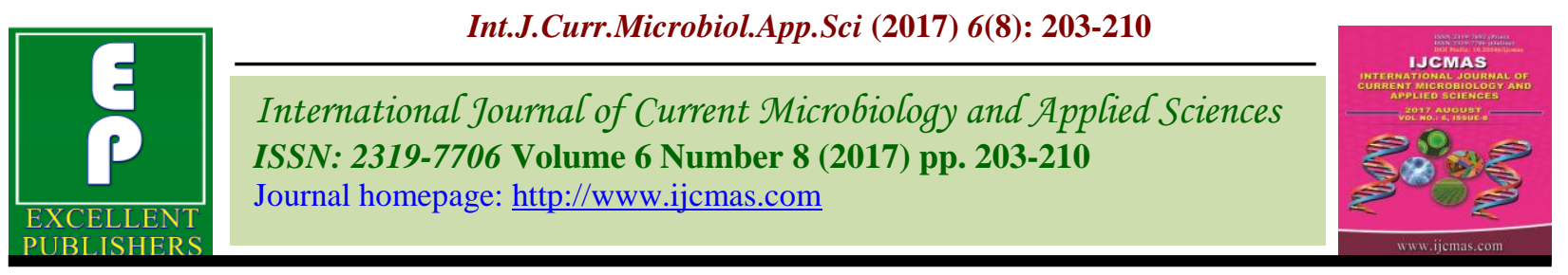

Original Research Article https://doi.org/10.20546/ijcmas.2017.608.028

\title{
Isolation and Identification of Klebsiella pneumoniae using API-20E analytical system and conventional PCR assay
}

\author{
Abeer Ghassan Munther Al-Agha ${ }^{1 *}$, Nazar Jabar Muslih Al-Khafaji ${ }^{2}$ and \\ Amer Khazal Salih Al-Azawi ${ }^{1}$ \\ ${ }^{1}$ Department of Microbiology, College of Veterinary Medicine, \\ University of Diyala, Diyala, Iraq \\ ${ }^{2}$ Department of Medicine, College of Veterinary Medicine, University of Diyala, Diyala, Iraq \\ *Corresponding author
}

Keywords

Klebsiella, API$20 \mathrm{E}, w b b Z$ gene

Article Info

Accepted:

04 June 2017

Available Online:

10 August 2017
A B S T R A C T

Klebsiella spp., particularly Klebsiella pneumoniae, are important causes of nosocomial infections due to the presence of capsular polysaccharide which is a major surface-located virulence properties associated with the pathogenesis of Klebsiella pneumoniae. The capsule is an elaborate polysaccharide matrix that encases the entire cell surface and provides resistance against many host defense mechanisms. D-galacton II has an important role in synthesising the lipopolysaccharide of Klebsiella pneumoniae and many other gram negative bacteria. This study included the isolation of Klebsiella pneumoniae bacteria from different sources in the environment and identification by using API-20E system and a conventional Polymerase chain reaction assay which detects Klebsiella pneumoniae $w b b Z$ gene that involved in expression of $\mathrm{D}$-galacton. The results of our study confirmed the positive identification of the bacteria using API-20E analytical system and also the presence of wbbZ gene in two of Klebsiella pneumoniae tissue invasive strains using conventional PCR assay.

\section{Introduction}

Klebsiella is one of the most important members of Klebsiella genus in Enterobacteriacae family, which is responsible for pneumonia (Puspanadan et al., 1998). Besides it is found to cause infections in the urinary and lower biliary tract (Lopes, et al., 2005; Ryan, 2004).

Klebsiella species were found to be the most frequently isolated gram negative bacteria in cases of primary bacteremia (Cross A., 1983). It is the second pathogen, next to E. coli that causes urinary tract infection. It normally affects persons with low immune system such as hospital patients, diabetes patients and people with chronic lung disease. Many a times, alcoholics also suffer from $K$. pneumoniae infections.

Thus, the infections are either hospitalacquired or community-acquired (Sikarwar and Batra, 2011).

Characteristically, Klebsiella spp. produce large mucoid colonies because of the synthesis of large amounts of capsular 
polysaccharide (CPS). There are 72 recognized $\mathrm{K}$ antigen serotypes of Klebsiella spp., which are based on the structures of the CPS (Kenne and Lindberg, 1983).

\section{The genus Klebsiella}

\section{General characteristics}

The genus Klebsiella is non-motile, nonsporulating, lactose-fermenting, oxidase negative, and Gram-negative with a prominent polysaccharide capsule of considerable thickness which gives the colonies their glistening and mucoid appearance on agar plates. Klebsiella is rod shape $0.3-1 \mu \mathrm{m}$ in diameter and 0.6-6 $\mu$ min length arranged singly, in pairs or in short chains.

Klebsiella is facultative bacteria and the colonies appear large, mucoid, and red with diffusing red pigment on MacConkey agar indicating fermentation of glucose and acid production. Klebsiella are normal inhabitant of the intestinal tract of human and animal, soil, water and botanical environment (Ørskov 1984; Podschun and Ullmann 1998; Brisse et al., 2006).

\section{Classification}

The bacterial genus Klebsiella was designated in honor of the German microbiologist (Edwin Klebs by Trevisan in 1885), who also described the Klebsiella pneumoniae species in 1887.

Historically, the classification of Klebsiella species, like that of many other bacteria, was based on their pathogenic features or origin. Taxonomic keys were proposed that included characteristics such as substrate utilization and enzymatic activities.

A great confusion has prevailed in Klebsiella nomenclature (Kanki et al., 2002) with new bacteria being synonymous with species already proposed (Grimont et al., 2000; Hedegaard et al., 1999; Podschun and Ullman, 1998) or with the reclassification of some species even within other genera (Drancourt et al., 2001).

Based on DNA-DNA hybridization data $K$. ozaenae and $K$. rhinoscleromatis, taxonomically, are regarded as subspecies of $K$. pneumoniae (Podschun and Ullmann, 1998; Drancourt et al., 2001).

\section{Pathogenesis and clinical importance}

$K$. pneumoniae is the most medically important species of the group. $K$ oxytoca and $K$. rhinoscleromatis have also been demonstrated in human clinical specimens (Podschun and Ullmann, 1998).

$K$. pneumoniae is also a potential communityacquired pathogen (Ko et al., 2002).

In humans, Klebsiella species may colonize the skin, pharynx, or gastrointestinal tract.

They may also colonize sterile wounds, urine and may be regarded as normal flora in many parts of the colon, intestinal and biliary tract (Podschun and Ullmann, 1998; Brisse et al., 2006).

\section{Materials and Methods}

\section{Collection and isolation of bacteria}

At the period from September 2016 to March 2017, 40 samples from different sources were collected as follows:

\section{Culturing of isolates}

The samples which transported to the laboratory were inoculated into nutrient broth at $37^{0} \mathrm{C}$ for $5 \mathrm{hr}$. (enrichment step) to increase bacterial level. 
Loopful from the incubated broth was streaked onto each surface of MacConkey agar then incubated at $37^{\circ} \mathrm{C}$ for $24 \mathrm{hr}$.

Identification of some selected pathogenic bacterial isolates using API-20E analytical system (confirmation test)

This system was used for approving the diagnosis of bacterial isolates and study the rest of the biochemical tests for $\mathrm{K}$. pneumonia.

The test conducted as (Atlas et al., 1995) according to the French manufactured company (BioMarieux).

\section{Procedure out line}

Oxidase test performed prior to inoculation.

\section{Preparation of strip}

A $5 \mathrm{ml}$ of sterilized distal water were added to the holes of the tray in order to provide humidity conditions then the strip was put in the tray.

\section{Preparation of bacterial suspension}

Three to four bacterial colonies isolated from MacConkey agar culture were suspended in a test tube filled with $5 \mathrm{ml}$ of phosphate buffer saline.

\section{Inoculation of strip}

The upper and lower part of caplets were filled with bacterial suspension by a sterile Pasteur pipette of the following caplets (CIT, VP, GEL) as for the rest of caplets only the lower part were filled with the suspension to concave line.

The lower part filled with sterile liquid paraffin in order to provide anaerobic conditions to the following caplets $\left(\mathrm{H}_{2} \mathrm{~S}\right.$,
URE, ADH, LDC, ODC). The band was covered and incubated for 24 hour at $37^{\circ} \mathrm{C}$.

\section{Reading of strip}

After incubation period the following reagents were added:

A drop of Kovac's reagent to IND caplet and read immediately.

A drop of Ferric chloride $10 \%$ to TDA caplet and read immediately.

A drop of VP1 to VP caplet then a drop of VP2 were added and read after 10 minutes.

On the result page, the tests were separated into 7 sets and a number (1,2 and 4$)$ is specified for each test. Every positive result has given its own number while the negative result is zero.

Adding the numbers correspondingly to results within each group, a 7-digit profile numbers were attained and then compared with numbers that found in the analytical profile index for documentation of tested bacterium (Fig. 1).

\section{Molecular identification using PCR technique}

\section{Extraction of DNA}

Samples tubes were mixed thoroughly, and then DNA was extracted from each sample by using Wizard Genomic DNA purification kit (Promega, USA) with modification according to the following protocol:

A loop full of activated colony culture grown for 18-20 hours was added to a $1.5 \mathrm{ml}$ micro centrifuge tube containing 200 $\mu 1$ of TE buffer and then mix by vortexing. The samples were centrifuged at 13,000 rpm for 2 minutes and then the supernatant was removed. For cell 
lysis, $600 \mu \mathrm{l}$ of Nuclei Lysis Solution was added to the cell pellet and gently pipet to mix. Mixture was incubated for $15 \mathrm{~min}$ at $70^{\circ} \mathrm{C}$. For RNA removal, $4 \mu \mathrm{l}$ of RNase solution was added to the cell lysate and inverted 2-5 times to mix. It was incubated at $37^{\circ} \mathrm{C}$ for $15 \mathrm{~min}$, and then it was cooled to room temperature.

To start DNA purification, $300 \mu \mathrm{l}$ of Protein Precipitation Solution was added to the RNase-treated cell lysate and vortexed at high speed for 20 secs. Then it was incubated on ice for 5 mins, centrifuged at $13000 \mathrm{rpm}$ for 10 min. Diluting DNA was transferred to a clean $1.5 \mathrm{ml}$ microcentrifuge tube containing $600 \mu \mathrm{l}$ of isopropanol to start DNA concentrating step.

The tube was then gently mixed by inversion until the thread-like strands of DNA form a visible mass, centrifuged at $13000 \mathrm{rpm}$ for 2 mins. The supernatant was carefully poured off and the tube was drained on clean absorbent paper. Five hundred microliter of $70 \%$ ethanol was added and the tube was gently inverted several times to wash the DNA pellet, centrifuged at $13000 \mathrm{rpm}$ for $2 \mathrm{mins}$ and ethanol then was aspirated carefully. The tube was drained on clean absorbent paper and the pellet was allowed to air-dry at room temperature for $10-15$ mins.

One hundred microliter of DNA Rehydration Solution was added to the tube and rehydrated the DNA by incubating at $56^{\circ} \mathrm{C}$ for $1 \mathrm{hrs}$, solution was mixed by gently tapping the tube. The resultant DNA was stored at $2^{\circ} \mathrm{C}$.

\section{Primers selection}

All primers (Table 2) were supplied in lyophilized forms. Dissolved in nuclease-free water to give a final concentration of 100 picomo $/ \mu 1$ as recommended by provider and stored in deep freezer as stock solution until used in PCR amplification. Work solution was prepared by added $90 \mu 1$ of nuclease free water to $10 \mu \mathrm{l}$ of stock solution of primer to get $10 \mathrm{picomol} / \mu \mathrm{l}$ concentration.

\section{Oligonucleotide primers}

The oligonucleotide primer sequences were used for amplification of the highly conserved region of target gene from bacterial isolates as previously described by Hsieh et al., 2014. The sequence of the forward primer KP0663+228 -F was 5' AGGATTGTA TTCTGAAGGTC $3^{\prime}$ and for the reverse primerKP0663 - $\mathrm{R}$ was 5' TCAACTTGC CGTAATAAAGC 3' will produce expected product of $567 \mathrm{bp}$. Primers were obtained commercially from Sigma, USA.

\section{Determination of DNA concentration and purity}

Quantus florometer was used to detect the concentration of extracted DNA in order to detect the goodness of samples for downstream applications. For $1 \mu 1$ of DNA, $99 \mu 1$ of diluted Quanty Flour Dye was mixed. After incubation at room temperature for $5 \mathrm{~min}$, DNA concentration values were determined.

\section{Results and Discussion}

\section{Isolation}

From a total 40 samples which represents 9 urine samples from healthy and sick persons in hospitals, 16 swabs from operation room of a hospital, 3 river water, 8 salad vegetables, 2 milk samples from a cow and 2 swabs from sheep nose Klebsiella spp. were isolated only 3 urine samples and 2 swabs from sheep nose were positive to be Klebsiella pneumoniae on MacConkey agar, further more only 2 (1 urine sample and 1 sheep nose swab) were subjected to API-20E analytical test and PCR assay and proved to be positive Klebsiella pneumoniae (Tables 1-6; Fig. 2). 
Table.1 Total number of samples

\begin{tabular}{|l|l|}
\hline Samples & Total No. \\
\hline Human Urine samples & 9 \\
\hline Swabs from operation room of Baqubah's hospital & 16 \\
\hline Water from Diyala's river & 3 \\
\hline Salad vegetables & 8 \\
\hline Cow's milk & 2 \\
\hline Sheep nose & 2 \\
\hline Total & 40 \\
\hline
\end{tabular}

Table.2 The primers and their sequences used in conventional PCR technique

\begin{tabular}{||l||l||l||l||l||}
\hline Primer & Primers sequences (5`-3) & Target gene & Size & Reference \\
\hline KP0663+228-F & AGGATTGTATTCTGAAGGTC & $w b b Z$ & $567 \mathrm{bp}$ & Hsieh et al., 2014 \\
\hline KP0663 - R & TCAACTTGCCGTAATAAAGC & $w b b Z$ & $567 \mathrm{bp}$ & Hsieh et al., 2014 \\
\hline
\end{tabular}

Table.3 Reaction volume and components of PCR

\begin{tabular}{|l|l|l|}
\hline Components & Conc. & Volume $(\boldsymbol{\mu l}) \backslash$ Reaction \\
\hline GoTaq PCR master mix & $2 \mathrm{X}$ & $10 \mu \mathrm{l}$ \\
\hline Forward Primer & $10 \mu \mathrm{M}$ & $1 \mu \mathrm{l}$ \\
\hline Revers Primer & $10 \mu \mathrm{M}$ & $1 \mu \mathrm{l}$ \\
\hline DNA & $10-50 \mathrm{ng}$ & $6 \mu \mathrm{l}$ \\
\hline Neuclease-free water & - & $2 \mu \mathrm{l}$ \\
\hline Total per reaction & $20 \mu \mathrm{l}$ \\
\hline
\end{tabular}

Table.4 Thermal cycle programming

\begin{tabular}{|l|l|l|l|}
\hline Steps & $\mathbf{C}^{\circ}$ & min:sec & Cycles \\
\hline Initial Denaturation & $95 \mathrm{C}^{\circ}$ & $5 \mathrm{~min}$ & 1 \\
\hline Denaturation & $95 \mathrm{C}^{\circ}$ & $30 \mathrm{sec}$ & \multirow{3}{*}{35} \\
\hline Annealing & $53 \mathrm{C}^{\circ}$ & $30 \mathrm{sec}$ & \\
\hline Extension & $72 \mathrm{C}^{\circ}$ & $30 \mathrm{sec}$ & 1 \\
\hline Final Extension & $72 \mathrm{C}^{\circ}$ & $7 \mathrm{~min}$ & 1 \\
\hline Hold & $4 \mathrm{C}^{\circ}$ & - & \\
\hline
\end{tabular}

Table.5 Total number of samples and the isolates from them

\begin{tabular}{|l|l|l|l|l|l|l|l|}
\hline Type of samples & \multirow{2}{*}{$\begin{array}{l}\text { Total } \\
\text { No. }\end{array}$} & \multicolumn{6}{|c|}{ No. of isolates } \\
\cline { 3 - 8 } & & Klebsiella & E. coli & Proteus & Salmonella & Fungi & Pseudomonas \\
\hline $\begin{array}{l}\text { Urine samples from } \\
\text { human }\end{array}$ & 9 & 3 & 4 & 2 & - & - & - \\
\hline $\begin{array}{l}\text { Swabs from operation } \\
\text { room of hospital }\end{array}$ & 16 & - & - & 4 & 3 & 5 & 4 \\
\hline Water from river & 3 & - & 3 & - & - & - & - \\
\hline Salad vegetables & 8 & - & 5 & 3 & - & - & - \\
\hline Cow's milk & 2 & - & - & - & - & 2 & - \\
\hline Sheep nose & 2 & 2 & - & - & - & - & - \\
\hline Total & 40 & 5 & 12 & 9 & 3 & 7 & 4 \\
\hline
\end{tabular}


Table.6 API-20E

\begin{tabular}{|l|l|l|l|}
\hline Test & Code & Negative result & Positive result \\
\hline$\beta$-galactosidase & ONPG & Colorless & Yellow \\
\hline Arginie Dihydrolysis & ADH & Yellow & Red-orange \\
\hline Lysine Decarboxylase & LDC & Yellow & Red-orange \\
\hline Ornithine Decarboxylase & ODC & Yellow & Red-orange \\
\hline Citrate Utilization & CIT & Yellow & Green-blue \\
\hline Hydrogen Sulfide & H2S & Colorless & Black sediment \\
\hline Urease production & URE & Yellow & Red-orange \\
\hline Tryptophan Deaminase & TDA & Yellow & Dark brown \\
\hline Indole production & IND & Yellow ring & Red ring \\
\hline Acetone production & VP & Colorless & Pink-red \\
\hline Gel Hydrolysis & GEL & No pigments & Black pigments \\
\hline Glucose & GLU & Blue & Yellow \\
\hline Manitol & MAN & Blue & Yellow \\
\hline Insonitol & INO & Blue & Yellow \\
\hline Sorbitol & SOR & Blue & Yellow \\
\hline Rhaminose & RHA & Blue & Yellow \\
\hline Sucrose & SAC & Blue & Yellow \\
\hline Melibiose & MEL & Blue & Yellow \\
\hline Amayloid & AMY & Blue & Yellow \\
\hline Arabinose & ARA & Blue & Yellow \\
\hline & & & \\
\hline
\end{tabular}

Fig.1 API-20E test showing the 7-digit profile number according to positive and negative results that confirms the diagnosis of Klebsiella pneumoniae $97 \%$ in the

API-20E analytical profile index book

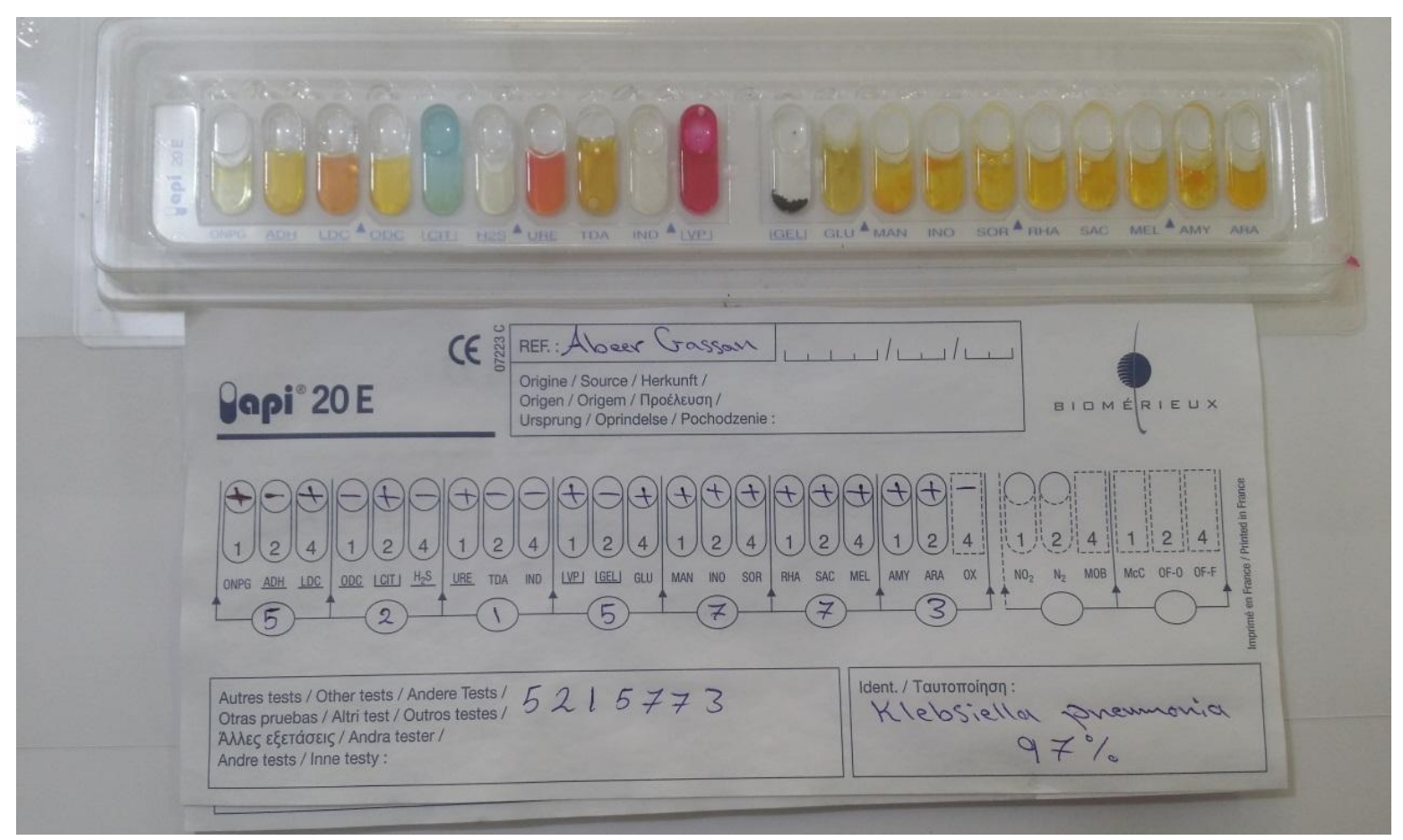


Fig.2 Agarose gel electrophoresis PCR product of a $567 \mathrm{wbbZ}$ gene in tissue invasive Klebsiella pneumoniae. Lane 1 is M, represents the 100-bp ladder DNA marker; Lane 2 is a urine sample from a patient while Lane 3 is a swab from sheep nose

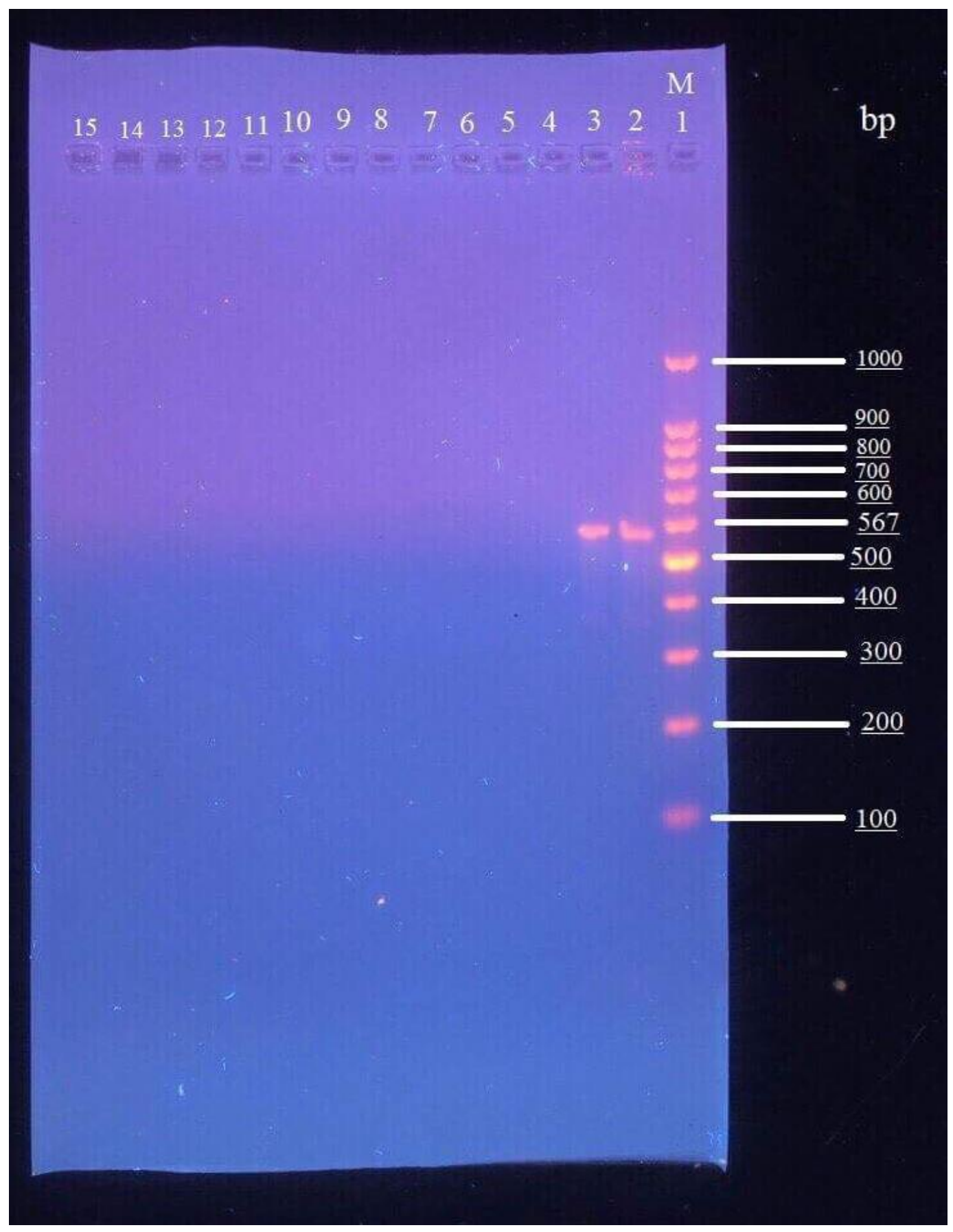

\section{Identification of isolates}

On MacConkey agar a large dome shaped highly mucoviscous colonies of lactose fermenting bacteria were grown confirmed by string test reaching $6 \mathrm{~mm}$ in length. Then smears were prepared from the isolated colonies on a glass slide and stained by Gram stain. Short Gram- negative rods of bacteria appears in stained smear. 


\section{References}

Atlas R.M., Parks L.C. and Brown A.E. (1995). Laboratory manual of experimental microbiology. 1st ed. Mosby-Year Book. Inc. U.S.A.

Brisse S., Grimont F. and Grimont P.A.D. (2006). The Genus Klebsiella. Prokaryotes; 6:159-196.

Cross A., Allen J.R., Burke J., Ducel G., Harries A., John J., Johnson D., Lew M., McMillan B., Meers P., Skalova R., Wenzel R.and Tenney J. (1983). "Nosocomial infections due to Pseudomonas aeroginosa". Review of recent trends. Rev. Infect. Dis., 5: 837 845.

Drancourt M., Bollet C., Carta A., Rousselier P. (2001). Phylogenetic analyses of Klebsiella species delineate Klebsiella and Raoultella gen. nov, with description of Raoultella ornithinolytica comb. nov, Raoultella terrigena comb. nov. and Raoultella planticola comb. Nov, Int J Syst Evol Microbiol., 51:925932.

Grimont F., Grimont PAD., Richard C. (2000).The genus Klebsiella. In: Dworkin et al., (eds) The Prokaryotes, 2nd ed, Springer Verlag, New York.

Hedegaard J., Steffensen SA de A., NørskovLauritsen N., Mortensen KK., SperlingPetersen HU. (1999) Identification of Enterobacteriaceae by partial sequencing of the gene encoding translation initiation factor 2. Int J Syst Bacteriol., 49:1531-1538.

Kanki M., Yoda T., Tsukamoto T., Shibata T. (2002) Klebsiella pneumoniae produces no histamine: Raoultella planticola and
Raoultella ornithynolytica strains are histamine producers. Appl Environ Microbiol., 68:3462-3466.

Kenne L. and Lindberg B. (1983). Bacterial polysaccharides, The polysaccharides. In: G.O. Aspinall (Ed.), Academic Press, Inc., New York. 2: Pp. 287-363.

Ko W.C., Paterson D.L., Sagnimeni A.J., Hansen D.S., Von Gottberg A., Mohapatra S., Casellas J.M., Goossens H., Mulazimoglu L., Trenholme G., Klugman K. P., McCormack J.G. and $\mathrm{Yu}$ V.L.(2002). Community-acquired Klebsiella pneumoniae bacteraemia: Global differences in clinical patterns. Emerg. Infect. Dis., 8(2):160-166.

Lopes A.C.D.S., Rodrigues J. F. and Morais M.A.D.(2005). Molecular typing of Klebsiella pneumoniae isolates from public hospitals in Recife, Brazil. Microbiological Research., 160:37-46.

Ørskov I. and ØrskovF. (1984). Serotyping of Klebsiella. Methods Microbiol., 14:143-164.

Podschun R. and Ullmann U. (1998). Klebsiella spp. as Nosocomial Pathogens: Epidemiology, Taxonomy, Typing Methods, and Pathogenicity Factors. Clinical Microbiology Review., 11(4): 589-603.

Ryan K.J. and Ray C.G. (2004). Sherris Medical Microbiology (4th Ed.). McGraw Hill.

Sikarwar A.S. and Batra H.V. (2011) Challenge to healthcare: Multidrug resistance in Klebsiella pneumoniae. International Conference on Food Engineering and Biotechnology., 9: $130-134$.

\section{How to cite this article:}

Abeer Ghassan Munther Al-Agha, Nazar Jabar Muslih Al-Khafaji and Amer Khazal Salih AlAzawi. 2017. Isolation and Identification of Klebsiella pneumoniae using API-20E analytical system and conventional PCR assay. Int.J.Curr.Microbiol.App.Sci. 6(8): 203-210. doi: https://doi.org/10.20546/ijcmas.2017.608.028 